\title{
UMA ANÁLISE DA FUNÇÃO DOCENTE NA ERA LÍQUIDA SOB O ESPECTRO DA FILOSOFIA
}

\author{
Eliane Juraski Camillo ${ }^{1}$
}

\begin{abstract}
Resumo
O presente artigo, resultado de revisão bibliográfica, se ocupa de uma análise da função docente na era líquida, realizada sob o espectro da filosofia. O texto se propõe a refletir e problematizar a função docente e alguns de seus principais entraves na atualidade, como a perda do papel de centralidade do professor no âmbito da educação, bem como a ausência de ócio dos professores que trabalham com a educação básica e seus desdobramentos, tanto os que incidem para esses professores de modo direto, enquanto sujeitos, quanto àqueles que possuem implicações para a educação como um todo. Para se chegar a esse objetivo, o texto, primeiramente, resgata, objetivamente, o caminho percorrido pela filosofia no decorrer de sua historicidade, indicando, através da visão de Dalbosco (2003), a relação existente entre a filosofia e a pedagogia, nem sempre produtiva, a qual precisa ser modificada, com a filosofia, por intermédio de seu papel reflexivo, auxiliar a educação a constantemente revisar seu papel e suas práticas, auxiliando-a a buscar soluções para suas problemáticas, dentre as quais, a apontada nesse artigo. Através de Bauman (2008), é esmiuçada a sociedade líquida, racionalidade na qual os problemas da educação e da função docente vêm acontecendo. Em suas conclusões, o artigo apresenta algumas pistas no sentido de edificar uma educação melhor para todos, através da valorização da função docente, agente de extrema importância na busca pela autonomia e emancipação, bem como no resgate da humanização no mundo líquido.
\end{abstract}

Palavras chave: Educação. Função Docente. Sociedade Líquida.

\section{AN ANALYSIS OF THE TEACHING FUNCTION IN NET AGE UNDER THE PHILOSOPHY SPECTRUM}

\begin{abstract}
This article is the result of literature review deals with an analysis of the teaching function in the liquid was held in the shadow of philosophy. The text aims to reflect and discuss the teaching function and some of its major obstacles today, as the loss of centrality of the role of the teacher in education, as well as the absence of idleness of teachers working with basic education and their developments, both those that relate to these teachers directly, as subjects, as those who have implications for education as a whole. To achieve this goal, the text, first, rescues, objectively, the path taken by philosophy in the course of their history, indicating, through the visionof Dalbosco (2003), the relationship between philosophy and pedagogy, not always production, which needs to be modified, with the philosophy, through his reflective paper, auxiliary education constantly reviewing its role and practices, helping her to seek solutions to their problems, among which pointed to this article. By Bauman (2008), is teased net society, rationality in which the problems of education and the teaching profession have been going. In their conclusions, the article presents some clues in order to build a better education for all, through the enhancement of the teaching role of utmost importance in the quest for autonomy and emancipation, as well as the rescue of humanization in the world liquid agent.
\end{abstract}

Keywords: Education. Teaching Profession. Liquid Society.

\section{Considerações Iniciais}

\footnotetext{
${ }^{1}$ Doutoranda em Educação pela UFSM de Santa Maria-RS. Mestre em Educação pela UNISC de Santa Cruz do Sul-RS. Possui graduação em Letras pela Universidade Regional Integrada do Alto Uruguai e das Missões - URI - FW. Email: juraskicamillo@gmail.com
} 
Ao encetar considerações sobre a educação, circunscrita no estudo da filosofia, prescinde tecer alguns comentários sobre a última. É possível inferir que a razão é oriunda dos gregos, como totalidade resultante de logos (razão) e mythos (narrativas primordiais sobre a natureza e os homens). Os gregos tinham a imagem subjetiva de um mundo concebido como um eterno retorno, onde se podia contemplar a natureza, bem como as ações dos homens na polis, no sentido de promover uma vida boa na mesma.

Na Idade Média, a razão integra-se à tradição judaico-cristã, identificando-se com Deus, que passa a ser o logos, sendo que a filosofia se submete à teologia. Já na Renascença, o homem descobre a razão como subjetividade inerente a ele, a qual inevitavelmente, conduz ao conhecimento - filosófico, científico e teológico.

No período compreendido entre o século XVI a XVIII, a filosofia passa de guardiã do fundamento para juíza das condições do conhecimento, reservando-se o direito de separar as esferas da cultura (ciência, arte, técnica, moral e política); enquanto que do século XIX a XX, ocorre a matematização da experiência, sendo que a filosofia auxilia na tarefa de clarificar a linguagem da ciência. Isso se dá num contexto muito peculiar de mudanças radicais, mediatizadas pelo advento do capitalismo, pela revolução industrial e pelas guerras mundiais.

Na era moderna ocorre, também, a virada linguística, caracterizada pelo deslocamento da questão do sujeito para as linguagens, além do surgimento de novos paradigmas em oposição ao lógico-científico (complexidade, autopoiésis).

Concernente ao papel da filosofia na contemporaneidade, cumpre asseverar que a mesma ocupa um lugar bem mais modesto que outrora, sobressaindo-se como a grande questionadora da realidade, circunscrita na virada computacional e o caráter volúvel da informação, trazendo diversos tipos de razão e pretensões de racionalidade.

Ao se aproximar escola e filosofia, Dalbosco (2003) sentencia a existência de uma relação vertical e improdutiva entre a filosofia e a pedagogia. A filosofia tensiona ditar os fundamentos para a pedagogia, considerando-a um conhecimento deveras inferior, enquanto que a pedagogia, por sua vez, ignora a filosofia, por considerá-la demasiadamente abstrata e sem sentido na aplicação prática dos problemas do cotidiano da educação.

O autor acrescenta, ainda, que há uma espécie de divisão do trabalho entre a filosofia e a pedagogia, numa relação simbiótica: enquanto que a filosofia se ocupa com o problema da fundamentação, a pedagogia deve assumir a motivação moral para se seguir normas devidamente fundamentadas. 
E é com âncora na feição reflexiva da filosofia que se tentará problematizar acerca da função docente frente às inúmeras problemáticas que cerceiam o rol do seu fazer, no afã de trazer humildes contribuições para a questão, na exaustiva tarefa de se buscar a der stein der weisen (DALBOSCO, 2003) - elucidação e compreensão, procurando abarcar uma realidade educacional cada vez mais densa e complexa, a qual somente poderá ser melhor apreendida à luz da filosofia.

\section{Em cena, a função docente na sociedade líquida}

Parafraseando Ernildo Stein, em conferência no Colégio Metodista em Ijuí, em 1994, questiona-se: Como irá viver futuramente o professor, pólo tão importante no processo de ensino/aprendizagem, situado no contexto da sociedade líquida? Essa questão assume posição de centralidade, haja vista que a educação parece assumir o epicentro das discussões na sociedade atual, tanto na mídia, quanto em congressos e seminários, com presença obrigatória também nos discursos governamentais, como condição sine qua non para que um povo alcance desenvolvimento e progresso, além do indivíduo atingir autonomia e emancipação.

Mas, afinal, por que os holofotes estão permanentemente voltados para a questão da educação? Segundo Streck (2004), o homem é um ser dotado de educabilidade, ou seja, uma propensão natural em direção ao conhecimento. É pela educação que o homem percorre a distância de onde ele é, até onde ele pode chegar. E, consoante o filósofo Ernest Bloch, o homem nunca é todo o homem, consequentemente, a sociedade nunca é toda a sociedade. Dada a sua condição de inacabamento, o ser humano é considerado um ser-em-possibilidade, com pulsão ontológica para o ser-mais. E a resposta afirmativa a esse chamado somente pode ser dada pela educação. Assim como as plantas se movem em direção da luz, assim como os animais são guiados pelos seus instintos e procuram sanar suas necessidades mais urgentes, o homem se move rumo ao conhecimento, na tentativa de saciar sua sede de ser-mais.

E, pode-se seguramente afirmar, sem titubear, que a educação, em tempos de contemporaneidade, está em profunda crise, assim como o Estado, a família, as instituições de modo geral. Aliás, mesma em uma análise mais superficial, é possível inferir que o vocábulo "crise" está tão em voga, que certamente há equívocos e abusos em seu emprego. Não obstante essa observação seja uma negação de sua existência e onipresença. A educação está, sim, em crise, não está sendo vetor de emancipação e humanização, mas um mero treino para o mercado de trabalho, esvaziando-se, transfigurando-se em um não-valor, seu próprio contrassenso. O Estado, mergulhado em profunda crise, não mais consegue assegurar os direitos básicos dos cidadãos (estes, em muitos 
ensejos, nem sabem que não o são). E a família segue o mesmo rumo, desarticulada, com fome de comida, de emprego, de dignidade, com visíveis sinais de ruptura.

Todavia, dentre as várias acepções do termo crise, destaca-se a cosmovisão gramsciana, de que crise compreende o período no qual o velho ainda não morreu e o novo ainda não nasceu. Um período de transição, matizado pela incerteza, até que o novo possa, finalmente triunfar; não sendo necessário, porém, um rompimento definitivo com o velho. O novo poder ser o velho transviado de outras roupagens, uma reformulação ou uma adequação do mesmo. Dessa forma, a afirmação de que a sociedade está em crise pode ser uma oportunidade ímpar de reflexão sobre suas bifurcações, na intenção de se tecer uma racionalidade que dê conta de entendê-la, movendo-se a passos resolutos rumo às transgressões das quais não se pode abdicar.

E qual é a racionalidade que se sobrepuja atualmente? Em Bauman (2008) encontram-se os elementos primordiais quando a intenção é compor o vasto caleidoscópio da sociedade contemporânea, denominada pelo autor de líquida. E essa sociedade, segundo o sociólogo polonês, é ingentemente distinguida pela presença ubíqua do medo, que é a denominação das incertezas, da ignorância, da ameaça e do que deve ser feito, do que pode e do que não pode para fazê-lo recuar ou enfrentá-lo, quando a cessação do mesmo foge do controle humano.

A Europa do século XVI caracterizava-se pelo Peur toujors, peur partout - medo sempre e em toda a parte (Lucien Febvre, in Bauman 2008), numa época de agudização das incertezas. Porém, a modernidade, a qual estava sendo gestada e parecia ser a panacéia, o fim de todos os medos, fracassou, pois hoje, mais do que nunca, se está à mercê do medo.

Para Bauman (2008), o medo é compartilhado por homens e animais, sendo que ambos oscilam entre reações de fuga ou de agressão. Entre os seres humanos, o medo que impõe intrépido é o medo de segundo grau, medo derivado ou secundário, o qual é inerente ao comportamento humano, geralmente sob a forma de resquícios de experiências passadas. O medo derivado é um sentimento de insegurança, um estado de suscetibilidade e vulnerabilidade ao perigo, tendo a consciência de que, se algo acontecer, as chances de defesa são reduzidas ou simplesmente nulas.

Já os perigos dos quais se tem medo são de três tipos: os que ameaçam o corpo e a propriedade, os mais gerais que se levantam contra a ordem social e a confiabilidade (renda, emprego, invalidez, velhice), e os perigos que dirigem contra o lugar da pessoa no mundo hierarquia, identidade, imunidade à degradação e à exclusão.

Até então, o Estado mantinha um acordo tácito com o indivíduo: protegia-o em troca de sua obediência. Com a desterritorialização via globalização, não mais consegue cumpri-lo, deslocando a luta contra o medo para o nível individual, que se configura no crescente armamento 
da população, na busca desenfreada por proteção, na procura por alarmes, grades, enfim, todo um aparato que, embora grandioso, não é garantia absoluta de segurança e tranqüilidade. Esse é um dos maiores paradoxos do mundo líquido, que mesmo com o exacerbado desenvolvimento que permitiu a produção massiva de enésimos artefatos, ainda assim, a sociedade se sente insegura e desprotegida.

O autor chama a atenção para a ubiqüidade do medo. Ele está em todo o lugar e pode vir de qualquer direção: da natureza, no aumento insidioso das catástrofes; de outras pessoas, através de crimes, inveja, intrigas; sem contar de uma terceira zona, muito mais incerta, como jatos que caem sem razão aparente, sabotagens, entre outros. Desde o nascimento até a morte, empreende-se diligências infinitas em uma luta ferrenha contra os medos que assombram, os quais se deslocam com extrema fluidez.

Vive-se o silenciamento silencioso, que é o acostumar-se a administrar a presença do medo, vivendo constantemente sob a ameaça de algo, embora boa parte do que se proclama não acontece. Um exemplo disso foi o bug do milênio, que atormentou milhares de usuários de computadores, sendo que nada realmente aconteceu. Como a economia de consumo depende da produção de consumidores, "cria-se" o mal, e, juntamente com ele, oferece-se o antídoto, obviamente, por determinado preço e com a melhor das intenções em ajudar (grifo meu), desembocando no consumismo sem precedentes.

Vive-se, também, a crédito. A geração atual é, indiscutivelmente, segundo Bauman (2008), a mais endividada de que se tem notícia. Antigamente, os bons governos buscavam equilibrar receitas e despesas. Hoje, o bom governo é aquele que consegue controlar o excesso de despesas. Há um uso equivocado do carpem diem - que dantes significava aproveitar a vida, fazer algo de bom, ou então viver o ócio - sendo que hoje significa "para que esperar para amanhã, se é possível (com o cartão de crédito) consumir hoje?".

Embora se proclame, a alto e bom som, a democracia e a liberdade total vivem-se na neblina. Com certo grau de liberdade, não se nega, mas ainda assim, na neblina. A ausência do ócio, o bombardeio de informações ao qual se está permanentemente exposto, impedem que as informações sejam objetos de reflexão, sendo que sua interpretação acaba ficando apenas na superficialidade, podendo se ver e prever somente o que está bem próximo.

$\mathrm{Na}$ ótica de Bauman (2008), a sociedade líquida sofre da "síndrome do Titanic", não sendo à toa o fato de o filme ter sido um campeão inconteste de bilheteria. Ora, os "icebergs" estão em toda a parte, não tendo como prever sua exata localização. E, mesmo que tivesse, o choque é inevitável. Detalhe: não há coletes salva-vidas para todos. Enquanto uns morrem disputando um 
colete ou um lugar no bote, outros morrem ouvindo música, como se nada de grave estivesse acontecendo, tentando preservar e manter o status quo.

O conto moral predileto do mundo líquido é o sucesso desmedido dos reality shows, que, em sua tônica, nada mais são do que pessoas tentando excluir outras pessoas para não serem excluídas. Os "big brothers" ensinam que a punição é a norma, e a recompensa, exceção. Os vencedores são aqueles que escapam da sentença universal da eliminação. Os vínculos entre a virtude e o pecado, entre a recompensa e a punição são tênues.

No mundo líquido, os medos surgem numa sucessão contínua e estonteante, enfraquecendo a capacidade de um eficaz enfrentamento, o que dependeria de uma sinergia, o que não é possível devido ao individualismo que reina soberanamente. Proclama-se que os desastres ocorrem de forma aleatória, sem motivo ou explicação aparente, havendo um elo muito débil entre o que os homens fazem e o que lhes acontece, sendo que pouco ou nada pode se fazer para evitar tal sofrimento. Alardeia-se sobre a ameaça maligna e a iminência da eliminação, além da impotência do ser humano em fugir disso, o que dissemina o medo de forma intermitente, sem jamais se visualizar a redenção.

Em relação à morte, Bauman (2008) vaticina que a mesma anula a ideia de esperança, de futuro. É a mais incognoscível dos desconhecidos. Por mais que as pessoas se preparem para a morte, ela as pega despreparadas, anulando todos os conhecimentos e habilidades, adquiridos em vida. Os sofistas acreditavam que o medo da morte era contrário à razão (quando eu estou, a morte não está; e quando a morte está, eu não estou mais). Contudo, estavam enganados, pois, onde eu estiver, o medo da morte estará sempre comigo. "Todas as culturas humanas podem ser decodificadas como mecanismos engenhosos calculados para tornar suportável a vida com a consciência da morte." (BUAMAN, 2008, p. 46).

A humanidade tem negado a finalidade da morte, preferindo encará-la como uma passagem deste mundo para outro, através da ressureição ou reencarnação. A conclamação para se viver bem esta vida está justificada na promessa de recompensa para a outra. O pecado original elevou o valor da vida corpórea, o fato de o homem ser herdeiro do mesmo, obriga-o a não apenas evitar de se fazer o mal; mas praticar boas ações, auto-sacrifício, autoimolação para afastar o estigma.

Inverter os pesos em relação à morte foi outro estratagema utilizado para robustecer o sentido da vida. Ou seja, o sentido da morte passa de fim, para entrada triunfal no céu, a eternidade ao alcance dos mortais. Contudo, incentiva-se a deixar de aproveitar as primícias desta vida em nome de algo superior que nunca ninguém testemunhou. 
Outra racionalidade do mundo líquido é a quase obrigação de se realizar feitos imemoráveis, para que, depois da morte, outras possam evocar recordações - o frutificar. É a tão cobiçada individualidade, que se efetiva pela conservação da ipséitè (deixar marcas, diferenciar-se das massas). A individualidade, de acordo com o sociólogo polonês, é algo muito desejável, sobrevivendo às custas das massas. A fama - ser mantido na memória da posteridade - é o melhor meio de atingi-la. Porém, de forma paradoxal, para alcançá-la, prescinde pertencer a uma categoria que garanta a consagração, tendo, a fama, feições de antinomia: concomitantemente consagra os que não apresentam deslizes, e condena à infâmia os que se desvirtuam, pelo mínimo que seja.

Para as massas, as quais não conseguem atingir o acima descrito, têm como opção perseguir uma imortalidade personalizada, já que não possuem vida atraente, tampouco real possibilidade de ser autor de algum feito memorável, podendo se distinguir pela morte, doar-se a uma causa. Isso pode ser operacionalizado pelo pacto indivíduo-Estado, por exemplo, que seria morrer na guerra. Embora seja considerada a perda pessoal (da família, pai/irmão/marido), é um regozijo para a nação e razão de imortalidade na memória coletiva, pelo feito heroico. Em Streck (2004) há um claro exemplo disso. O autor se reporta a personagem Sofia, da obra Emílio, de Rousseau, descrevendo que ela será uma mãe exemplar, uma mãe republicana que, em caso de guerra, enviará um filho seu sem a menor hesitação, para que ele lute pela sua pátria de forma aguerrida. Na hipótese de um escravo vir, entre lágrimas e soluços, avisá-la de uma eventual morte do filho, será severamente repreendido. Antes Sofia perguntará se a batalha fora vencida, se o filho cumpriu sua missão em defesa do Estado, para só depois chorar, de forma circunspecta, sua morte.

Na sociedade líquida, onde as tendências supra descritas parecem ter perdido a força, surge um ardil substituto, melhor descrito com as próprias palavras de Bauman (2008, p. 56). “...a marginalização das preocupações com o fim mediante a desvalorização de tudo que seja durável, permanente, de longo prazo." Isto é, como se torna cada vez mais difícil conseguir notoriedade, imortalidade, despreza-se tais valores. Quem não recorda a fábula da raposa e das uvas, que após exaustivas tentativas de alcançá-las, a raposa desiste, sob alegação de que não as queria mesmo, por estarem verdes? Degrada-se, assim o valor da eternidade, centrando toda a importância da vida no momento presente. Separa da morte o seu horror, disponibilizando-o para outros usos, o que se caracteriza como sua desconstrução e banalização.

A desconstrução reside no hábito de se tentar justificar o injustificável, que no caso específico significa tentar encontrar a causa mortis - que é o que os médicos tentam incansavelmente buscar, visto que as causas naturais, de certa maneira, os desqualificam, sem contar que os familiares não se satisfazem com tal explicação. Acredita-se que, eliminando uma a 
uma as causas da morte, consiga-se vencê-la. As dietas mirabolantes que o digam! A cada dia são descobertas novas fórmulas, entre alimentação, prática de esportes, capazes de prolongar a duração da vida. O efeito, porém, é contraproducente, não afastando nem a morte, que é inevitável, tampouco o medo dela. As pessoas se policiarão as vinte e quatro horas do dia, evitando tudo que possa causá-la. Ao invés esconjurar o medo, ratifica-o. A válvula de escape consiste na diluição deste medo nas várias ações, entre uma dieta e outra a se fazer e a se evitar. Se esse pavor fosse ingerido de uma tragada só, paralisaria o desejo de viver, seria a morte na vida.

Apenas a perda definitiva de pessoas próximas e queridas faz entender totalmente e fatalmente os conceitos de singularidade e de terminalidade. Essas pessoas levam consigo um pouco do mundo das pessoas que ficam, sendo impossível preenchê-lo, trazendo solidão e vazio. A morte de um cônjuge sinaliza o rompimento definitivo de uma relação, significando a morte de segundo grau para aquele que fica. Também o rompimento de uma relação e suas consequentes feridas, sem indícios de reconciliação, configura a morte de terceiro grau.

A morte de terceiro grau vem se tornando algo muito recorrente, beirando à banalização. Acontece que, na era líquida, os relacionamentos se tornaram tão levianos e os laços tão débeis, que se desfazem e se fazem novamente indistintamente. Nesse interstício, a morte perde toda a aparência de mistério, a fera se converte em animal doméstico, numa lamentável fragilidade de vínculos humanos.

A morte contida no rompimento de laços é intencional e premeditada, aproximando-se da noção de assassinato ou de homicídio. Divide os envolvidos entre perpetradores e vítimas, pois dificilmente se dá sem conflitos e por vontade de ambos. De um lado, o rompimento é sempre bem vindo, significando libertação; enquanto que do outro, dolorosa rejeição. Neste caso, o medo da morte é o medo de ser excluído.

A morte metafórica pode acontecer com qualquer um dos parceiros, que se cansou ou percebeu oportunidades melhores com outro (a), desferindo primeiro o golpe fatal. Como no mundo líquido não existem mais valores universalmente aceitos, os juízos são particularizados, de forma que se torna ineficaz o excluído tentar provar sua inocência. O que para uns é candura, para outros é tolice. Por isso que o grau de vitórias nesses tribunais pessoais é dimensionado em direção aos que têm mais poder e menos escrúpulos, e não para o lado dos mais justos.

O objetivo fundamental da sociedade líquida é a busca individual da felicidade, num empreendimento igualmente individual. A vida líquida é um campo de batalha permanente, onde os inconvenientes para a busca dessa felicidade devem, a qualquer preço, serem afastados. As vitórias, por sua vez, são temporárias. 
A nível macro, a humanidade atingiu a capacidade de autodestruição. Se não a extinção total da vida no planeta, a das condições de vida, resultado direto de se tentar tornar o planeta mais hospitaleiro e confortável (para alguns, é claro).

[...] metade do comércio mundial e mais da metade do investimento global beneficiam apenas 22 países que abrigam só $14 \%$ da população mundial, enquanto que os 49 países mais pobres recebem apenas $1 \%$ da renda combinada dos três homens mais ricos do planeta (BAUMAN, 2008, p. 98).

O bem-estar, lastimavelmente, é um privilégio de alguns. É parte integrante do sistema, não uma falha dele, como alguns tentam demonstrar. Os que usufruem as benesses não têm a ínfima intenção de universalizá-las. Conforme o autor em voga, são utilizados recursos globais para sustentar desfrutes locais.

O homem, no limiar da modernidade, tinha a presunção de corrigir e administrar a natureza, no intuito de submergir o tipo de comportamento que se quisesse para que se tornasse universal - direito natural (Kant). Ao contrário, ao invés de caminhar para o natural, dirigiu-se abruptamente para a irracionalidade desmedida.

E a globalização é a zênite, a consagração da racionalidade esmiuçada até então no escopo deste artigo. Desgraçadamente, a globalização que impera é extremamente negativa, pois não vislumbra horizonte de mudança aos marginalizados - maioria absoluta. A tão fadada abertura é sinônimo de "globalização altamente seletiva do comércio e do capital, da vigilância da informação, da coerção e das armas, do crime e do terrorismo, todos os quais agora desdenham a soberania nacional e desrespeitam quaisquer fronteiras entre os Estados." (BAUMAN, 2008, p. 126). Esse modelo de globalização traz vulnerabilidade e incerteza, acentuando o medo. Numa globalização negativa, os problemas são globais, sendo ineficiente soluções locais, até porque eles foram globalmente gerados e fortalecidos.

Concatenado com a globalização, o ideário neoliberal apregoa uma sociedade regida pela liberdade de mercado, dando possibilidades iguais a sujeitos diferentemente munidos, o que é no mínimo exasperador. É dar permissão explícita para o leão devorar sua presa vorazmente, mesmo que ela seja uma criancinha indefesa. E isso é aplicável a todas as esferas sociais, inclusive na educação. Paira no ar uma iminente tendência - ou seria mais adequado dizer ameaça - de privatização do ensino. A própria LDB traz de maneira subliminar essa disposição, ao incentivar que empresas privadas financiem parte da educação pública.

De Rossi (2004) se manifesta a respeito do assunto, expondo o resultado de uma pesquisa aplicada em cinco países (Inglaterra, Nova Zelândia, Austrália, Estados Unidos e Suécia), onde a educação pública funciona segundo os moldes do mercado. Foi averiguado que não houve melhoras 
na educação, nenhum avanço. Ao contrário, aumentou consideravelmente a estratificação social, agudizando-se as diferenças entre os privilegiados e os marginalizados. Tal sistema beneficiou apenas os privilegiados, que afinal de contas, não necessitam de guarida, por já possuírem acesso garantido aos bens a às oportunidades. Por essa razão que é preciso intensificar a luta por uma educação pública de qualidade, pois somente ela poderá instrumentalizar os sujeitos que estão em desvantagem na escala social, para que possam trilhar com desenvoltura o caminho que os leva à emancipação, com vistas a transformar o mundo líquido que aí se descortina.

\section{Resgatando a função docente no mundo líquido}

Retomando a problemática que é a espinha dorsal deste artigo, afirma-se, consoante Arroyo (2000), que a educação vem sofrendo um processo de despersonalização. No imaginário coletivo, ao tratar-se da educação formal de uma criança, possível por intermédio da escola, pensase imediatamente na escola, não na figura do professor. Joãozinho foi um bom aluno e hoje é um exímio profissional em sua área de atuação porque estudou na escola Santo Cristo. Não se declara que Joãozinho foi um bom aluno e hoje é um exímio profissional porque foi aluno dos professores Carlos e Eva, os quais desempenhavam a função docente com total esmero. Fazendo-se uma analogia com a área da saúde, faz-se logo menção ao médico, nunca ao hospital. Felipe teve uma pancreatite, todavia sua saúde foi logo restabelecida, pois se tratou com o médico Cristiano, excelente profissional; no lugar de declarar que Felipe melhorou rapidamente porque foi atendido no hospital Ana Nery. Deduz-se, daí, que, ao contrário do médico, o professor gradativamente perdeu seu lugar de centralidade na educação, tornando-se um apêndice do sistema.

A função docente, qualificada por Arroyo (2000) através da expressão "ofício de mestre", resgata todo valor que a mesma possui, mesmo diante de tão ignóbil realidade. Prova contundente da importância da mesma é que, embora desvalorizada pelos ditames da sociedade líquida, sobreviveu a todas as investidas do mundo tecnológico, das mudanças na formatação do mercado de trabalho, entre outras variáveis.

Mesmo que a educação à distância tenha se consolidado, alastrando-se ininterruptamente, é consenso que nada, absolutamente nada substitui o professor. Máquina alguma, computador ou robô algum foi capaz de tal façanha até então. Como a presença do mestre é vital no caminhar do aluno, como uma palavra, um gesto, o contato tópico, um elogio, um conselho, fazem todo o diferencial em prol da aprendizagem, do amadurecimento, do desenvolvimento, do progresso de crianças/adolescentes/jovens! Comumente, os indivíduos esquecem em que votaram na última eleição, por exemplo. Mas nenhum jamais esquece do primeiro professor. Nem os mais 
desmemoriados. Geralmente, todos os professores são guardados na memória, ou pelo menos a maioria deles. Mesmo aqueles que são recordados por atitudes negativas, por serem enérgicos demais, por terem protagonizado algum episódio desagradável. Não deixam de ser lembrados. E quantos são imitados? Muitos, certamente. Se o indivíduo é uma totalidade englobando tudo que o rodeia, tem sim, muito de seus mestres, tanto no sentido positivo, quando no negativo. Geralmente as pessoas costumam inspirar-se em algum professor, em ao menos algum quesito.

Outro aspecto que distingue a função docente é o grau de comprometimento que o profissional deve ter com a profissão. É-se professor, não se está professor (grifo meu). Salvo raras exceções - não se nega a existência de profissionais relapsos, como em qualquer outra área de atuação - mas a função docente, indiscutivelmente absorve do profissional muito mais do que as quatro, oito ou doze horas diárias despendidas em uma sala de aula. Requer muitas "horas extras" em casa, adentrando madrugadas, com pilhas de provas/trabalhos para corrigir, aulas criativas e instigantes para elaborar. Que outra profissão leva tanta tarefa para ser feita em casa?

O professor tem uma singularidade (magnífica) enquanto profissional. Consegue internalizar, ao mesmo tempo, diversas outras especialidades, as quais são ativadas no momento exato, quando uma situação assim o exigir. Transvia-se, principalmente, de médico(a), psicólogo(a), pai/mãe, enfermeiro(a), doando-se sem reservas, por mais resistente ou insensível que seja. Não há como um professor não se alegrar com os avanços de seus alunos, tampouco se deixar afetar pelos seus problemas, desencadeando o agir do "outro" profissional que coabita com ele.

É-se professor em tempo integral, as vinte e quatro horas do dia. O professor é sempre encarado como professor, esperando-se dele comportamento compatível - leia-se exemplar - em qualquer ocasião, mesmo mais informal, como numa festa, num bar, numa praia. Quando qualquer outro profissional comete algum deslize, por menor que seja, em algum dos ambientes citados, o fato passa despercebido, caindo logo no esquecimento. O mesmo não ocorre com o professor. Como é criticado, como é alvo de maledicências, como é vilipendiado por menor que seja a razão. Às vezes nem razão precisa existir para que se desvirtue a figura do mesmo. Ele está sempre na berlinda, sempre por um fio.

Adorno explica, em parte, o desprestígio docente através dos tabus a respeito dos professores. Embora a referida teoria seja tecida em um outro contexto, o contexto alemão do pósguerra, não perdeu seu teor de atualidade, sendo perfeitamente aplicável à realidade líquida. $\mathrm{O}$ autor explica que existe no inconsciente coletivo um dúbio sentimento sobre a pessoa do professor. Por um lado, é admirado pelas suas qualidades cognitivas, por uma certa superioridade devido ao seu saber. Por outro, é rechaçado por distanciar-se demais das pessoas "normais", o que o torna alvo de 
inveja e de críticas. Remontando às suas origens, convém ressaltar que o professor era um escravo (que não tinha habilidade o suficiente para a guerra) e por isso era forçado a ensinar. Era destituído da força que realmente importava - a força física. Ainda hoje, entre os meninos, seus heróis são o super-homem e vários outros de se diferenciam pela habilidade física.

Adorno se refere à função do professor como um prevalecimento, já que no inconsciente coletivo predomina a imagem de um profissional que aplica sua força (que na verdade é uma pseudo força, pois é ineficaz contra o poder verdadeiro, oriundo dos que realmente o detém) contra crianças/adolescente indefesos. De um lado o professor, adulto, maduro, com o domínio do saber; de outro, o aluno, frágil, indefeso, inferior. Digladiam-se, para o inconsciente coletivo, forças inversamente proporcionais. E a situação do professor se agrava por completo quando o mesmo atua na educação básica, na rede pública; ao passo que o docente do ensino superior e da rede particular é visto de uma forma diferenciada. Este trabalha com adultos, com a formação profissional propriamente dita. Aquele trabalha com crianças. Este é autor, produz conhecimento. Aquele, na maioria das vezes se restringe a repassar o conhecimento produzido por outrem. E, o professor da rede pública carrega, ainda, mais um agravante em nome da diminuição de seu mérito enquanto tal. É funcionário público. É sanguessuga do Estado. Tem estabilidade de emprego, mesmo não o desempenhando com total zelo. E, atualmente, essa tendência ganha ainda mais ímpeto, sob o prisma do neoliberalismo, onde o Estado é considerado inoperante, retrógrado e fonte de todo mal, enquanto que a iniciativa privada é a origem de todo o bem.

O professor de educação básica de rede pública é um ser desprovido de esplendor, segundo a teoria adorniana. Um médico, um advogado (um juiz então!) são capazes de feitos memoráveis, sendo muito melhor remunerados que o professor. Um médico salva vidas. Um advogado, ou um juiz, podem ser elementos decisivos na elucidação de casos nos quais pessoas de muito poder político e/ou econômico possam acabar na prisão. E o professor, que faz? Trabalha com crianças/adolescentes. Aparentemente, nada de extraordinário. Só aparentemente.

O professor possui uma missão suprema, tão nobre quanto a do médico, que salva vidas. Ernildo Stein faz alusão ao fato de que as ciências humanas teriam mais direito ao erro se comparadas com as ciências exatas, por estas ter efeito mais direto, imediato e danoso à vida humana. Um erro médico, por exemplo, pode ocasionar a morte de um paciente. Ora, o professor, em sua ação, concorre par a educabilidade do ser humano. É o elemento indispensável no sentido de vicejar a possibilidade em uma criança, de responder afirmativamente à pulsão ontológica do sermais, de tornar a possibilidade realmente possível. Nessa perspectiva, desacertos são tão danosos quanto um erro médico. São igualmente letais. Senão imediatamente; porém, paulatinamente. Há 
algo mais desolador que anular a possibilidade em uma criança? Privá-la do direito de sonhar? Anular a esperança. Afinal, quando se perde a esperança, nada mais se tem a perder.

Cumpre asseverar, porém, que a empreitada docente, tendo o mundo líquido como pano de fundo, está se tornando cada vez mais custosa. Como despertar o discente para a possibilidade e para a esperança; se é o medo e a incerteza que formam o diapasão da vida líquida? Como robustecer tais valores face a uma sociedade tão insana, onde apenas uma minoria possui acesso pleno aos bens materiais e culturais, enquanto que a maioria absoluta padece no mundo da necessidade? Como o professor poderá se incumbir desta tarefa, se ele mesmo se encontra desesperançado, historicamente desvalorizado, diminuído enquanto profissional? Não levado em conta na tomada de decisões pertinentes ao seu próprio fazer? Embora se apregoe a alto e bom som a autonomia dos estabelecimentos de ensino, sabe-se perfeitamente que tal discurso é um ardil de um governo neoliberal, que não tem a menor intenção de promover mudanças de fato, nem na educação, nem em setor algum. A margem de autonomia cedida aos estabelecimentos de ensino não permite aos docentes poderem se mover com desenvoltura no terreno pedagógico, pois as decisões que incidem de forma mais abrupta no campo educacional são oriundas das instâncias superiores secretarias de ensino, MEC - quando não de organismos internacionais, como o Banco Mundial, sendo que o professor não é ao menos consultado.

E uma das questões de fundamental relevância acerca do magistério, principalmente os que atuam no nível básico, é a ausência do ócio. Este, segundo Enguita (1989), é essencial para ao ser humano. E o trabalho, como concebido no mundo líquido, ou seja, atividade regular e sem interrupções, intensa e na maioria das vezes carente de satisfações intrínsecas, é algo muito recente, datando do século XVIII, coincidindo com a passagem da produção de subsistência para o trabalho assalariado, configuração primordial do apogeu da industrialização e do capitalismo.

Enguita (1989) acentua a resistência popular, principalmente na Europa, frente ao trabalho fabril: fábrica e trabalho assalariado eram indesejáveis para os europeus, os quais consideravam dependência trabalhar para outros. Para o pensamento antiaristocrático da Europa medieval, a propriedade era a base da independência, a garantia de que ninguém se apropriaria do trabalho de outrem. Não imaginavam a sociedade dividida em minoria de proprietários e maioria que não possuíssem os meios de trabalho, como atualmente.

Embora as condições de vida e trabalho dos artesãos, trabalhadores domiciliares, camponeses, enfim, trabalhadores livres, fossem difíceis, o fato de lhes pertencer a capacidade de decisão sobre seu trabalho lhes dava independência material e ideal. O fato de trabalhar e morar no mesmo local significava que o trabalho era algo natural, prazeroso. Imagem de autonomia e 
dignidade, que não combinava com a condição de trabalhar de forma regular e constante para outra pessoa, sem poder decidir sobre sua própria atividade.

O problema não era apenas a questão moral - o submeter-se a outrem - a ânsia por independência, mas buscar equilíbrio entre o trabalho e o ócio, rompido pelo desejo desenfreado de lucros desmedidos dos capitalistas, ocasionando a ruptura de hábitos de trabalho e de vida arraigados, o que foi um verdadeiro choque.

Acontece que nossos ancestrais trabalhavam o suficiente para suprir suas necessidades materiais. Jamais trabalhariam quatro horas diárias, se com três horas já fosse o suficiente para se manter. Valorizavam mais o ócio que o dinheiro, por entenderam que aquele lhes fazia muito bem. Para os gregos e os romanos, na Idade Média, existiam muitos dias nefastos para o trabalho. Trabalhava-se muitas horas por dia, mas se podia parar quando quisesse.

Gradativamente, a nova ordem fora subvertida. A longa marcha do capitalismo, sua expansão, é resultado direto de um processo prolongado de lutas de classe, concorrência econômica e enfrentamento político, sendo a mais importante a organização das condições e da intensidade do trabalho. Instaurou-se uma política repressiva aos que não aceitavam a nova ordem social estabelecida, empreendendo-se perseguições implacáveis aos pobres, aos vagabundos, aos que não queria se submeter ao trabalho fabril, aos marginais, os quais foram subjugados ao trabalho forçado e a castigos corporais. O ócio deixou de ser parte inerente do homem. A preguiça passou a ser encarada como um mal terrível.

E na sociedade líquida o ócio tem estado muito ausente, principalmente entre os docentes. Como ter direito ao ócio, se o professor, ante à constante desvalorização salarial precisa trabalhar um número excessivo de horas diárias para suprir suas necessidades materiais? Conciliar, no caso específico das mulheres, a função docente com afazeres do lar por não ter condições de pagar uma empregada doméstica? Como ter direito ao ócio numa sociedade com formatações alteradas, onde a família precisa trabalhar cada vez mais em nome da sobrevivência ou da acumulação de bens (apelo latente do capitalismo), tendo cada vez menos tempo para o convívio familiar, para o diálogo com os filhos, passando este encargo para a escola, para o professor, numa espécie de terceirização (grifo meu) da educação dos filhos? Como fica o professor ante esta sobrecarga de trabalho? Cansado, esgotado, tendo uma péssima qualidade de vida, deprimido, doente.

Outro sério desdobramento da ausência do ócio entre os docentes incide na questão da formação. Desde a formação inicial, o professor, na maioria dos casos, já precisa aliar estudo e trabalho. Onde o tempo para consolidar uma base teórica consistente, haja vista que os muitos conteúdos precisam ser sorvidos vagarosamente, num processo de ampla reflexão? O que teria de 
ser um processo lento e prazeroso, metamorfoseia-se em algo atropelado. Mais uma vez difere de forma retumbante da formação inicial do médico, que estuda em tempo integral.

E as coisas só pioram quando o assunto é a formação continuada. Sem tempo livre, sem ócio (criativo), o professor se vê impedido de frequentar tais cursos. Se os frequenta, geralmente são feitos de forma aligeirada, com quase inexistência de dialogicidade, de encontro, de discussão, de reflexão, importando mais o certificado que o curso propriamente dito. Sem contar que os cursos strictu sensu são praticamente proibidos para o docente que atua na educação básica e em escola pública, pois o salário é simplesmente incompatível com o custo desses cursos.

Em conformidade com o discorrido, a teoria da semicultura e da semiformação, categorias adornianas de análise da sociedade, não perderam seu teor de atualidade. Mais do que nunca, a formação tem assumido ares de semiformação, enquanto que a cultura segue se transviando de semicultura. Se os docentes, responsáveis diretos pelo resgate da humanização da sociedade, se encontram mal formados e desumanizados enquanto pessoa e profissional, as referidas categorias continuarão a se perpetuar. E os sujeitos continuarão sujeitados, ao invés de emancipados, meras massas de manobra, consumidores em potencial de todo o lixo que o sistema produz.

\section{Considerações finais}

As constatações perquiridas no escopo deste artigo autorizam sustentar, de forma pragmática, o quão nobre é a função docente, urgindo, pois, resgatá-la, já que é ela que detém o poder de reaver a humanização, tão necessária para que, seguindo a linha de pensamento de Marcuse, o povo deixe de ser elemento de coesão social, para se tornar fermento de transformação, via transgressão.

Viabilizando esse horizonte utópico, e repudiando os anátemas em relação ao fazer do professor no contex to do mundo líquido dantes pormenorizados, conclama-se para o papel cabal da filosofia na árdua tarefa de provocar rupturas nesse círculo vicioso de esvaziamento e desvalorização da função docente.

Sem deixar de admitir que parte da culpa pelo atual estado das coisas em relação ao magistério pode, sem resquício de remorso algum, ser atribuída ao capitalismo desenfreado e sua ânsia desmedida pelo ter, demonstrando interesse periférico por assuntos tão importantes, como é o caso específico da educação, não se pode ficar somente nisso. Apenas culpar o sistema é insuficiente. Edificar uma nova racionalidade, onde a educação, assim como a figura do professor, possam ocupar o lugar de saliência que por direito lhes cabe, deve ser o "tema de casa" de todos os 
diretamente envolvidos - governantes, professores, pesquisadores, com âncora na filosofia e seu instrumento mais valioso: a reflexão.

Dessa forma, convém revitalizar a função docente por intermédio do diálogo, do encontro, da participação ativa na tomada de decisões acerca da sua própria profissão, bem como das políticas públicas que incidem, direta ou indiretamente, sobre a educação e a sociedade em geral. Ressalta-se, porém, que os resultados não serão imediatos, haja vista que, conforme Stein, as ciências humanas, que é onde a filosofia se impõe com mais intensidade, possui um ritmo diferenciado em relação às ciências naturais, demorando mais até que um conjunto de conceitos adquira certa valoração, assumindo ares de verdade. Proporcionalmente, também não passam tão rápido, demorando até perderem sua validade e serem substituídos.

Assim, para que os paradigmas - subjetividades pertencentes a grupos particulares, não sendo a expressão da vontade da maioria - que teimosa e perniciosamente persistem orquestrando os rumos da educação e do fazer docente sejam substituídos, é preciso mudanças significativas na gestão da educação, não apenas dos estabelecimentos, o que é insuficiente, mas do sistema como um todo; da clarificação do projeto político pedagógico, estabelecendo o ponto de partida, os meios e elegendo o ponto de chegada das instituições; a escolha de uma linha comum de ação, que vá ao encontro da humanização, da autonomia e da emancipação, libertando os sujeitos do pior analfabetismo, que na ótica de Pedro Demo é o analfabetismo político - o cidadão que nada mais é do que massa de manobra nas mãos dos poderosos, não participando ativamente na definição do seu próprio destino, mas desempenhando fielmente um script que o poder dominante o designou.

Resgatar a função docente, reavendo a humanidade do ser humano, tecendo, com letra indelével, uma nova Paidéia, que encerre todo o valor do homem, para que o mesmo possa se deslocar de seu ponto de origem até onde poderá vir-a-ser, compactuando com sua educabilidade: eis a grande tarefa da pedagogia e da filosofia no mundo líquido.

\section{Referências}

ADORNO, Theodor W. Tabus a respeito do professor. In: ZUIN, Antonio; PUCCI, Bruno; RAMOS-DE-OLIVEIRA, Newton. Adorno: o poder educativo do pensamento crítico. 3. ed. Petrópolis: Vozes, 2000.

ADORNO, Theodor. Teoria da semicultura. Educação e Sociedade, Campinas, ano XVII, n. 56, p. 388-411, dez. 1996. 
ARROYO, Miguel González. Ofício de mestre: imagens e auto-imagens. 2. ed. Petrópolis: Vozes, 2000.

BAUMAN, Zygmunt. Medo líquido. Rio de Janeiro: J. Zahar, 2008.

BLOCH, Ernst. O princípio esperança. Rio de Janeiro: Contraponto, [2005-2006].

DALBOSCO, Claudio Almir (Coord.). Filosofia prática e pedagogia. Passo Fundo: UPF, 2003.

DE ROSSI, Vera Lúcia Sabongi. Gestão do projeto político-pedagógico: entre corações e mentes. São Paulo: Moderna, 2004.

DEMO, Pedro. Avaliação qualitativa. 8. ed. São Paulo: Autores Associados, 2005.

ENGUITA, Mariano F. A face oculta da escola: educação e trabalho no capitalismo. Porto Alegre: Artes Médicas, 1989.

MARCUSE, Herbert. A ideologia da sociedade industrial. 4. ed. Rio de Janeiro: J. Zahar, 1973.

STRECK, Danilo R. Rousseau \& a educação. Belo Horizonte: Autêntica, 2004.

Recebido em: 24.07.2014

Aceito em: 20.10.2015 